\title{
Current and future applications of confocal laser scanning microscopy imaging in skin oncology (Review)
}

\author{
MIHAELA ADRIANA ILIE ${ }^{1,2}$, CONSTANTIN CARUNTU $^{3,4}$, MIHAI LUPU $^{5}$, DANIELA LIXANDRU $^{2}$, \\ MIRCEA TAMPA $^{6}$, SIMONA-ROXANA GEORGESCU ${ }^{6}$, ALEXANDRA BASTIAN $^{7,8}$, CAROLINA CONSTANTIN $^{8,9}$, \\ MONICA NEAGU ${ }^{8-10}$, SABINA ANDRADA ZURAC $C^{7,8}$ and DANIEL BODA ${ }^{1,4}$ \\ ${ }^{1}$ Dermatology Research Laboratory, Departments of ${ }^{2}$ Biochemistry and ${ }^{3}$ Physiology, 'Carol Davila' University of \\ Medicine and Pharmacy, 050474 Bucharest; ${ }^{4}$ Department of Dermatology, 'Prof. N. Paulescu' National Institute of Diabetes, \\ Nutrition and Metabolic Diseases, 011233 Bucharest; ${ }^{5}$ Department of Dermatology, MEDAS Medical Center, \\ 030442 Bucharest; ${ }^{6}$ Department of Dermatology, 'Victor Babes' Hospital, 'Carol Davila' University of Medicine and \\ Pharmacy, 030303 Bucharest; ${ }^{7}$ Department of Pathology, 'Carol Davila' University of Medicine and Pharmacy, \\ 050474 Bucharest; ${ }^{8}$ Department of Pathology, Colentina Clinical Hospital, 020125 Bucharest; \\ ${ }^{9}$ Department of Immunology, 'Victor Babes’ National Institute of Pathology, 050096 Bucharest; \\ ${ }^{10}$ Faculty of Biology, University of Bucharest, 050095 Bucharest, Romania
}

Received August 30, 2018; Accepted October 10, 2018

DOI: 10.3892/ol.2019.10066

\begin{abstract}
Confocal laser scanning microscopy (CLSM) is a modern imaging technique that enables the in vivo or ex vivo characterization of skin lesions located in the epidermis and superficial dermis with a high quasi-microscopic resolution. Currently, it is considered to be the most promising imaging tool for the evaluation of superficial skin tumors. The in vivo mode adds the advantage of noninvasive, dynamic, in real-time assessment of the tumor associated vasculature and inflammation. It offers the possibility to repeatedly examine the same skin area without causing any damage and to monitor disease progression and treatment outcome. Furthermore, this novel technology allows the evaluation of the entire lesion and can be used to guide biopsies and to define tumor margins before surgical excision or other invasive therapies. CLSM diagnostic features may differentiate between the various histologic subtypes of skin tumors and therefore helps in choosing the best therapeutic approach. In this study, we present the CLSM characteristic features of the most common melanocytic and non-melanocytic skin tumors, as well as future possible CLSM applications in the study of experimental skin tumorigenesis on animal models.
\end{abstract}

Correspondence to: Dr Constantin Caruntu, Department of Physiology, 'Carol Davila' University of Medicine and Pharmacy, 8 Eroii Sanitari Blvd., 050474 Bucharest, Romania

E-mail: costin.caruntu@gmail.com

Key words: in vivo, real-time, confocal imaging, quasi-microscopic resolution, skin tumors

\section{Contents}

1. Introduction

2. Application of reflectance confocal microscopy for skin cancer diagnosis

3. Application of confocal scanning laser microscopy for skin oncology research

4. Limitations and future perspectives

5. Conclusions

\section{Introduction}

Within recent years, dermatologic imaging technology focused on the development of optical, noninvasive tools to improve diagnostic accuracy and to overcome the disadvantages of histopathological examination. Of all these promising in vivo tools, only confocal laser scanning microscopy (CLSM) allows the visualization of cutaneous structures with a resolution that is very close to that of light microscopy, thus performing a skin 'optical biopsy' (1). It enables the noninvasive, virtual sectioning of the skin at different depths, with grey-scale images obtained in horizontal planes (en face), parallel to the skin surface and it does not require tissue processing or coloring $(2,3)$. As it allows repeated imaging of the same skin area in real-time, at different time intervals, it is an excellent method for monitoring disease progression and treatment efficacy and studying skin's dynamic behaviour (1,4-10).

Based on the source of image contrast, CLSM can be performed in either fluorescence or reflectance mode. Fluorescence confocal microscopy (FCM) requires the administration of a fluorescent agent to generate contrast (11) and has been used predominantly in experimental studies with promising results in lesional and nonlesional skin $(12,13)$. Reflectance confocal microscopy (RCM) relies on differences 
in the refractive indices of cellular structures (14) and has been extensively applied in the noninvasive assessment of melanocytic (15-18) and non-melanocytic skin tumors $(16,19)$, with features demonstrating a good correlation with dermoscopic and histologic findings. Furthermore, this novel imaging technique proved to be useful for the diagnosis of various inflammatory skin diseases (20), conditions with dermatologic manifestations (21), as well as for the study of dynamic processes like wound healing $(22,23)$, in real-time assessment of blood flow in response to various topical stimuli $(10,24)$ or leucocyte migration $(5,6)$.

Currently, in vivo RCM is considered to be the most promising noninvasive imaging technique for the quasi-microscopic morphological and dynamic characterization of superficial skin tumors. Moreover, it helps to define tumor margins before surgical excision or other invasive treatment modalities (19). Moreover, ex vivo settings may guide Mohs micrographic surgery $(25,26)$. Recently, novel multilaser devices, combining CLSM in reflectance mode with fluorescence techniques were developed, providing useful additional information when compared with the use of each variant of confocal microscope alone (13).

In this study, we present the RCM characteristic features of the most common melanocytic and non-melanocytic skin tumors (Table I), as well as future possible CLSM applications in the study of experimental skin tumorigenesis on animal models.

\section{Application of reflectance confocal microscopy for skin cancer diagnosis}

Basal cell carcinoma (BCC) is the most common of all cancers in light-skinned individuals (27) and its incidence is still rising with $\sim 10 \%$ each year worldwide (28). Very often, a skin biopsy is needed to confirm the diagnosis, despite its associated invasiveness and costs. Early diagnosis and treatment are of paramount importance because it is locally destructive and can lead to disfigurement $(29,30)$. RCM diagnostic features for various clinical types of BCC have been described (31-36), demonstrating a good correlation with certain dermoscopic and histopathologic findings $(37,39)$. BCC consists of aggregates of basaloid cells at the dermo-epidermal junction or papillary dermis that appear in RCM images either as 'bright tumor islands', cord-like structures surrounded by cleft-like dark spaces, either as 'dark silhouettes', hyporeflective dark areas outlined by bright stromal tissue $(36,38-40)$. These aggregates of basaloid cells often have nuclei that are oriented along the same axis, displaying a 'peripheral palisading' at the periphery of tumor islands $(35,36)$. In the above stratum spinosum, the elongated nuclei of keratinocytes that are polarized along the same axis form the typical 'streaming of the epidermis' (35). Additionally, prominent and tortuous blood vessels with intense leukocyte traffic are present in the dermis and numerous inflammatory cells with various shape and sizes (lymphocytes, melanophages) surround the tumor nests (36). In pigmented $\mathrm{BCC}$, bright dendritic structures that correspond to dendritic melanocytes can be identified inside aggregates of basaloid cells (41) (Fig. 1).

A retrospective, multicenter study evaluated the sensitivity and specificity of five RCM criteria for BCC, including architectural alteration and cellular pleomorphism of the overlying epidermis, areas of refractile tumor cells with elongated, monomorphic nuclei, nuclear polarization, increased dermal vasculature and prominent inflammatory infiltrate (35). Identification of two or more of these five criteria in a sample showed a sensitivity of $100 \%$ for BCC diagnosis, whereas four or more of these had a specificity of $95.7 \%$ and a sensitivity of $82.9 \%$ (35). Of these criteria, elongated, monomorphic nuclei proved to be the most sensitive $(100 \%)$ and nuclear polarization the most sensitive (91.6\%) and specific (97.1\%) (35).

Furthermore, this novel technology may be a diagnostic guide in defining the margins of the lesion before surgical excision (42) or laser ablation (29). During Mohs micrographic surgery, FCM proved to be far superior than RCM for tumor margin assessment in BCC (36). Moreover, it offers the advantage of monitoring noninvasive treatment in superficialtype BCC, thus avoiding the discomfort associated with skin biopsy $(43,44)$.

Squamous cell carcinoma (SCC) is the 2nd most frequent non-melanoma skin cancer after BCC and appears dominantly in sun exposed areas. Besides UV exposure, various risk factors, including immunosuppression, viral infections, exposure to chemical agents, neuro-endocrine factors or chronic inflammation, have been proposed to be involved in SCC pathogenesis (45-51). It has various clinical presentations including in situ lesions (Bowen's disease), invasive superficial lesions or highly infiltrative lesions (52). Actinic keratosis (AK) is the most common precancerous skin lesion with a risk of progression to a full-thickness SCC estimated at 5-10\% (53), but some authors consider it as an early form of SCC as it appears (54). Under RCM evaluation, SCC and hypertrophic AK often present a pronounced hyperkeratosis that limits the depth of penetration considerably (55) and provides whitewashed images because of the strong back-reflectance at the keratin-rich surface of the tumor (39). A more pronounced disarranged honeycomb pattern in the spinous-granular layers and the presence of neoplastic aggregates in the dermis can distinguish SCC from AK (56). Moreover, nuclei are enlarged and pleomorphic (55) and roundish, nucleated bright cells with a pagetoid arrangement are often observed in the suprabasal epidermis. When the thickness of the lesion allows the dermo-epidermal junction imaging, dermal papillae may appear elongated with looping, round vessels inside them $(39,57)$ (Fig. 2). However, in case of infiltrative lesions, the level of invasion is usually inaccessible in CLSM (58). Even with ex vivo CLSM during Mohs surgery, the detection of residual SCC is rarely possible also because of the non-reflecting features of keratinization $(58,59)$.

When it comes to RCM evaluation of SCC localized on the lips, distinctive features were described (60). Moreover, RCM evaluation has the potential to distinguish between features of normal mucosa, dysplasia and lip SCC in real-time and therefore may be useful for the preoperative assessment of tumor resection margins (61).

Cutaneous melanoma is one of the most aggressive human malignancies, associated with high mortality rates, despite latest advances in therapy (62-65). An important genetic background and several environmental factors are key players in melanoma development and progression (66-70). Two crucial points have to be taken into account in this form of aggressive 
Table I. Summary of the diagnostic reflectance confocal microscopy features for common skin cancers.

\begin{tabular}{|c|c|c|}
\hline Type of skin cancer & Reflectance confocal microscopy features & Author, year (Refs.) \\
\hline Basal cell carcinoma & $\begin{array}{l}\text { Bright tumor islands/dark silhouettes } \\
\text { Peritumoral clefting } \\
\text { Streaming of the epidermis } \\
\text { Prominent and tortuous blood vessels } \\
\text { Inflammatory cells } \pm \text { bright dendritic structures } \\
\text { Spoke wheel-like structures }\end{array}$ & $\begin{array}{l}\text { Caruntu et al, } 2014 \text { (33) } \\
\text { Ghita et al, } 2016 \text { (31) } \\
\text { González and Tannous, } 2002 \text { (36) } \\
\text { Longo et al, } 2014 \text { (32) } \\
\text { Nori et al, } 2004(35) \\
\text { Peppelman et al, } 2013 \text { (34) } \\
\text { Segura et al, } 2007 \text { (41) } \\
\text { Stephens et al, } 2013 \text { (37) } \\
\text { Ulrich et al, } 2010(38)\end{array}$ \\
\hline $\begin{array}{l}\text { Squamous cell } \\
\text { carcinoma }\end{array}$ & $\begin{array}{l}\text { Hyperkeratois } \\
\text { Disarranged honeycomb pattern with enlarged, } \\
\text { pleomorphic nuclei in the spinous-granular layers } \\
\text { Round, nucleated bright cells in the suprabasal epidermis } \\
\text { Elongated dermal papillae with looping, round vessels }\end{array}$ & $\begin{array}{l}\text { Aghassi et al, } 2000(55) \\
\text { Branzan et al, } 2006(58) \\
\text { Peppelman } \text { et al, } 2014(56) \\
\text { Que et al, } 2015 \text { (39) } \\
\text { Rishpon et al, } 2009 \text { (57) }\end{array}$ \\
\hline Melanoma & $\begin{array}{l}\text { Pagetoid spread of roundish or dendritic cells in the epidermis } \\
\text { Pleomorphic cells and atypical nests at the } \\
\text { dermo-epidermal junction } \\
\text { Non-edged papillae and atypical nucleated cells } \\
\text { in the papillary dermis } \\
\text { Poorly defined or absent keratinocytes cell borders }\end{array}$ & $\begin{array}{l}\text { Carrera et al, } 2012(80) \\
\text { Guida } \text { et al, } 2015(16) \\
\text { Pellacani et al, } 2007(15) \\
\text { Pellacani et al, } 2014(17) \\
\text { Ulrich and Lange-Asschenfeldt, } \\
2013 \text { (79) }\end{array}$ \\
\hline Mycosis fungoides & $\begin{array}{l}\text { Weakly refractile cells (lymphocytes), } \\
\text { Vesicle-like spaces (Pautrier collections) within the epidermis } \\
\text { Hypo-refractile papillary rings and dilated capillaries }\end{array}$ & $\begin{array}{l}\text { Agero et al, } 2007(90) \\
\text { Fabbrocini et al, } 2017 \text { (85) } \\
\text { Koller et al, } 2009(89) \\
\text { Lange-Asschenfeldt } \text { et al, } \\
2012(88) \\
\text { Li et al, } 2013(87) \\
\text { Mancebo et al, } 2016(86)\end{array}$ \\
\hline $\begin{array}{l}\text { Primary cutaneous } \\
\text { folliculocentric } \\
\text { lymphoma }\end{array}$ & $\begin{array}{l}\text { Round-shaped, highly-refractive tumor masses } \\
\text { Bright cells of various sizes and numerous bright small } \\
\text { cells (lymphocytes) at the periphery of tumor masses }\end{array}$ & Unpublished study \\
\hline
\end{tabular}

skin cancer. One is particularly in high-risk patients, where melanomas may be complicated to distinguish from nevi (71) and the fact that numerous biopsy specimens for screening are associated with patient morbidity. Therefore, if a dermatologist is confronted with a lesion obeying the ABCDE rule of melanoma (72) or if the atypical lesion is solitary/is the "ugly duckling' (73) there are no particular issues for a dermatologist. Conversely, in patients with numerous and clinically atypical nevi, visually identifying the lesion with the greatest atypical features that may represent a new or developing melanoma is almost impossible. Removing high numbers of nevi in such patients for finding one melanoma can be a screening method, but although there are extended publications on how many nevi should be removed in high-risk patients to identify one melanoma (74-77), there are still issues such as removing too few nevi can be associated with overlooked melanomas and/or significant medical system costs (78).

In particular, for this aggressive type of skin cancer RCM allows a noninvasive in vivo imaging at cellular-level from superficial melanomas to dermis invading melanomas. This important new tool has an emerging diagnostic role in the characterization of melanomas as a noninvasive in vivo histomorphological analysis and as an added device in following the clinical management of skin cancer patients (79).

In the case of melanoma, the melanocytic lesions have in the upper parts of the tumor pagetoid roundish or dendritic cells in the superficial epidermis, atypical nests at the dermo-epidermal junction, non-edged papillae and atypical nucleated cells in the papillary dermis. The benefit of RCM in vivo examination in real-time is important also in particular cases of melanoma like lentigo maligna melanoma and amelanotic melanoma. Moreover, this technology can add information on management of subclinical margins, recurrences, or monitoring noninvasive treatment of tumors (80).

Studies that focused on the application of this technology in melanoma diagnosis have shown that melanocyte-derived tumor cells can be demarcated from non-melanocytic ones. Thus, our experience has shown that, while benign nevi 

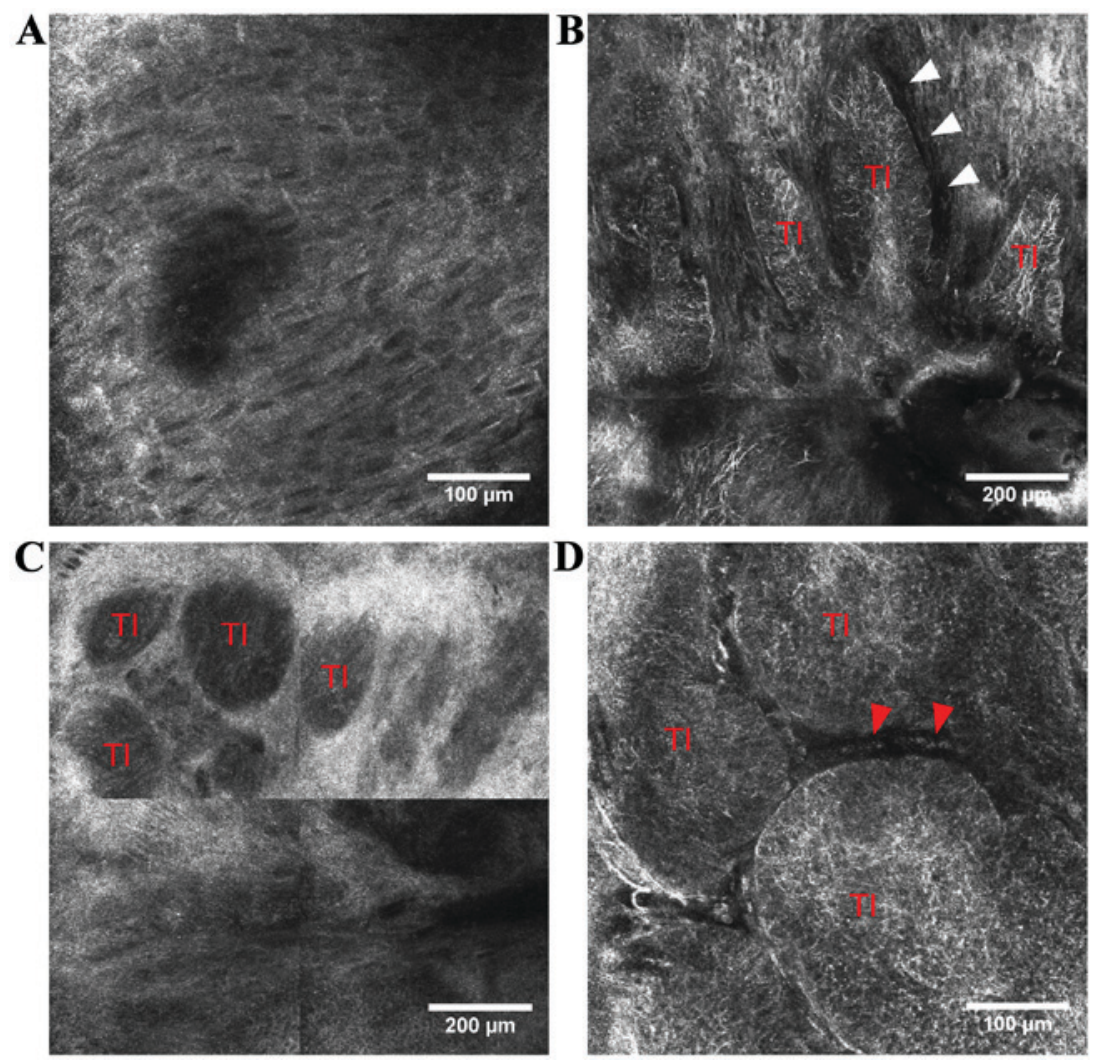

Figure 1. RCM features of BCC. (A) RCM image (500x500 $\mu \mathrm{m}$ ) showing polarization of keratinocytes along the same axis forming epidermal 'streaming'; (B) RCM mosaic $(1 \times 1 \mathrm{~mm})$ in the tumoral area of a pigmented BCC displaying elongated TI infiltrated by bright dendritic cells, peripheral palisading and peritumoral dark spaces (white arrowheads), also known as 'clefting'; (C) RCM mosaic (1x1 mm) showing 'dark silhouettes' representing TI, in the tumor region of a nodular BCC; (D) RCM image (500x500 $\mu \mathrm{m}$ ) of BCC showing TI infiltrated by dendritic cells and blood vessels (red arrowheads) surrounding the neoplastic dermal aggregates. TIs, tumor islands.
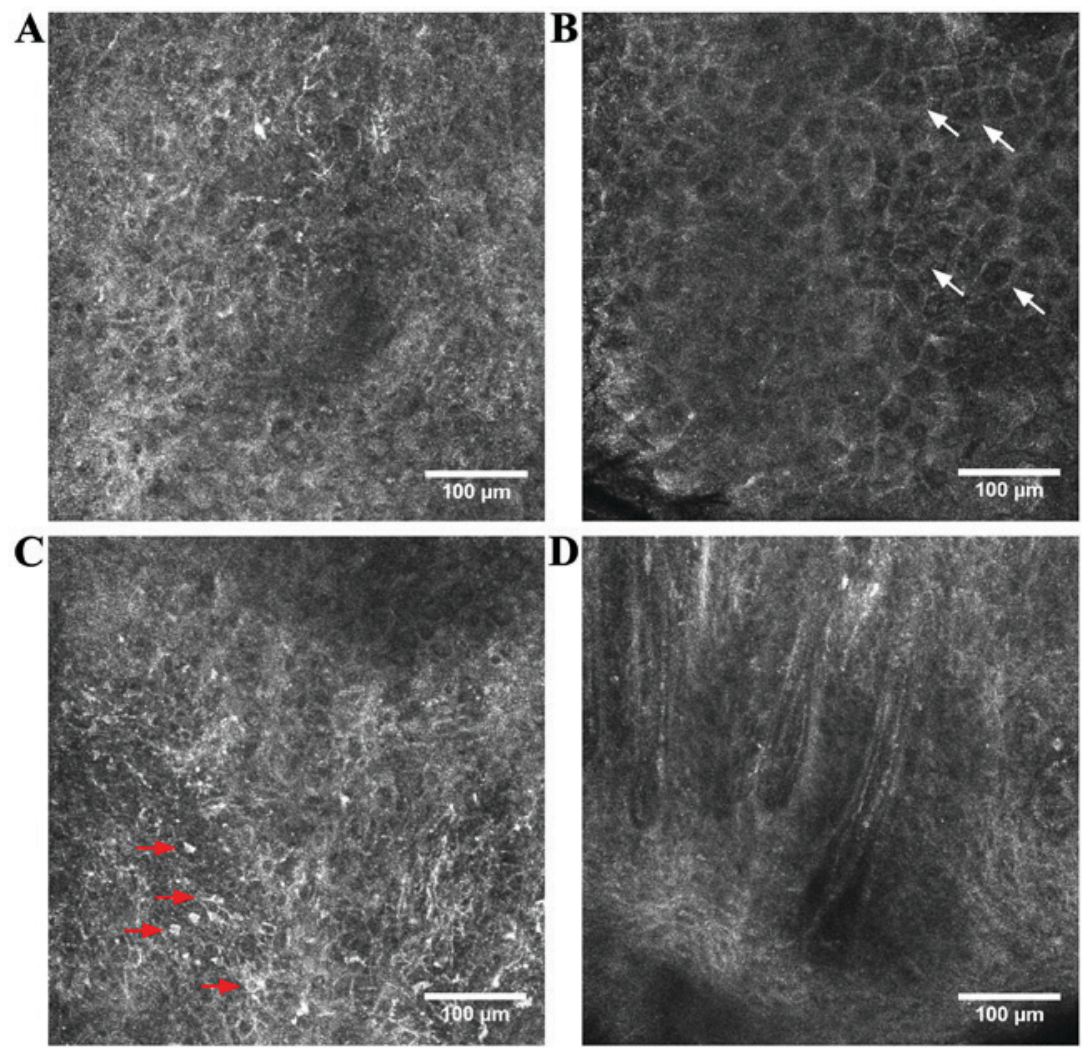

Figure 2. RCM features of SCC. (A) RCM image (500x500 $\mu \mathrm{m}$ ) of an atypical honeycomb pattern in the stratum spinosum; (B) RCM image (500x500 $\mu \mathrm{m})$ of dyskeratotic cells, also known as 'targetoid cells' (white arrows); (C) RCM image (500x500 $\mu \mathrm{m}$ ) at epidermal level showing roundish, nucleated, bright cells with a pagetoid arrangement (red arrows); (D) RCM image (500x500 $\mu \mathrm{m}$ ) showing looped vessels in the tumoral region of an SCC. 

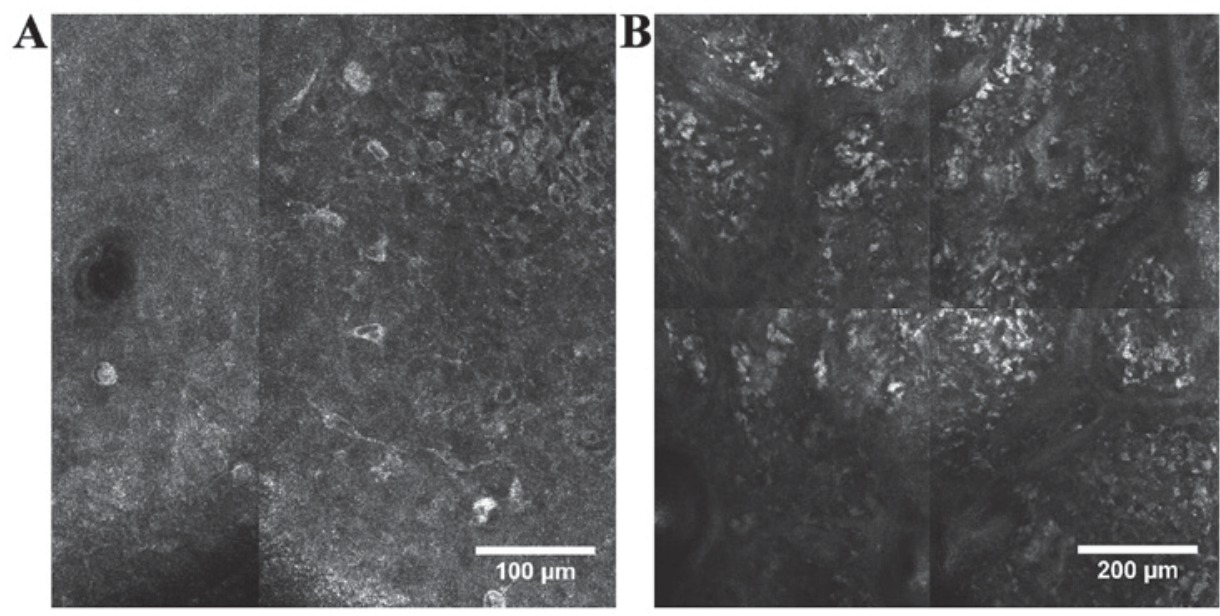

Figure 3. RCM features of cutaneous melanoma. (A) RCM image (500x500 $\mu \mathrm{m}$ ) displaying big, roundish and dendritic, bright, pagetoid cells infiltrating the epidermis; (B) RCM mosaic (1x1 mm) showing large heterogeneous nests of melanocytes with the presence of numerous atypical cells in the tumoral region of a cutaneous melanoma.

have monomorphic cells, round to oval in shape, with bright appearance, in melanomas cells are bright, polymorphic and irregular, roundish or with branching dendrites (Fig. 3). In benign nevi, junctional and dermal nevus cell nests can be found, while in melanomas there is a disarray of the melanocytic cell architecture. Keratinocyte cell borders can be detected readily but are poorly defined or absent in melanomas. The horizontal optical sections in RCM offer a better visualization of malignant melanocyte morphology than classical hematoxylin and eosin stained histologic sections $(15,81)$. In addition, based on their cell morphology in RCM, four types of melanomas have been identified, namely dendritic cell melanomas, melanomas with roundish melanocytes, melanomas with predominant dermal nesting proliferation and combined type melanomas, each with different tumor and patient characteristics (15).

More elaborated studies seeking to evaluate specificity and sensitivity of this technology have reported that there is a good differentiation between benign versus malignant tumors. Thus, depending on the observers, the sensitivity ranged from 90.42 to $97.62 \%$ and the specificity from 96.67 to $100 \%$. These values generated good performance of the investigation: sensitivity, $94.65 \%$; specificity, $96.67 \%$; positive predictive value $97.50 \%$; and negative predictive value $92.99 \%$ (82).

Gathering important information from large studies, this quasi-histological in vivo evaluation has no restrictions for age, sex, ethnicity and has a good association with clinical, dermoscopic and histopathologic findings. Therefore, diagnostic accuracy, sensitivity and specificity of the technique were a good backbone to implement it in the diagnosis of melanoma (16). This new technology brings, besides non-invasiveness characteristics, new mapping possibilities of difficult melanomas like lentigo maligna of the face (78).

Cutaneous lymphomas are a heterogeneous group of lymphoproliferative disorders involving the skin that are characterized by clonal proliferation of mature T-lymphocytes (>60\% of all cases), B-lymphocytes or NK cells $(83,84)$. Histopathological examination combined with immunohistochemistry of the skin biopsy specimen is the mainstay of the diagnosis, although sequential biopsies are often needed, especially in case of early stage lesions.

$\mathrm{RCM}$ has already been reported to be useful for the in vivo diagnosis (85-91) and therapeutic follow-up of cutaneous T-cell lymphomas (92), with the majority of studies referring to its most common type, mycosis fungoides (85-90) and one to lymphomatoid papulosis (91).

Mycosis fungoides, early patch lesions in particular, can imitate a wide variety of erythematosquamous skin diseases and its clinical and histopathological diagnosis is often a challenge. Most commonly reported RCM features of mycosis fungoides correlate with histopathologic findings and include weakly refractile cells (lymphocytes) and vesicle-like spaces (Pautrier collections) within the epidermis, hypo-refractile papillary rings and dilated capillaries with thick walls at the dermo-epidermal junction (90). Detection of Pautrier collections with RCM is associated with improved histopathologic diagnosis and presence of TCR gene clonality (86).

The rest of the RCM findings are non-specific and reflect the heterogeneous clinical and histopathologic presentation of the lesions (86). However, in vivo RCM seems to be reliable in guiding skin biopsy collection, therefore reducing the number of unsuccessful histopathological examinations for mycosis fungoides lesions $(85,87)$.

In contrast to cutaneous T-cell lymphomas, to date no RCM features have been described for the diagnosis of B-cell lymphomas. Our research team recently described the in vivo RCM features observed in primary cutaneous folliculocentric lymphoma lesions (unpublished results). These correlate with histopathology and include round-shaped, highly-refractive tumor masses in the dermis, bright cells of various sizes dispersed throughout the dermis and aggregates of bright small cells (lymphocytes) at the periphery of tumor masses (Fig. 4).

\section{Application of confocal scanning laser microscopy for skin oncology research}

Skin carcinogenesis is a complex, multifactorial process and the topic of intensive research given the continuously 

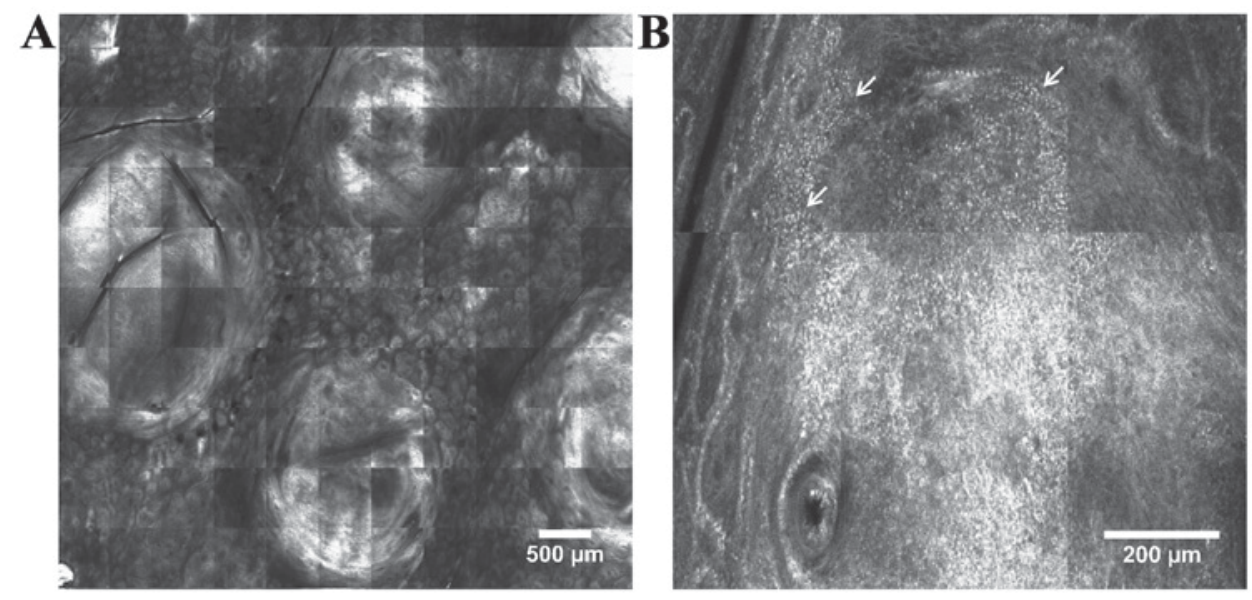

Figure 4. RCM features of cutaneous lymphoma. (A) RCM mosaic $(5.5 \times 5.5 \mathrm{~mm})$ showing well-demarcated, round-shaped, highly-refractive tumor masses; (B) RCM mosaic (1x1 mm) displaying aggregates of bright small cells (white arrows) at the periphery of a tumor mass.
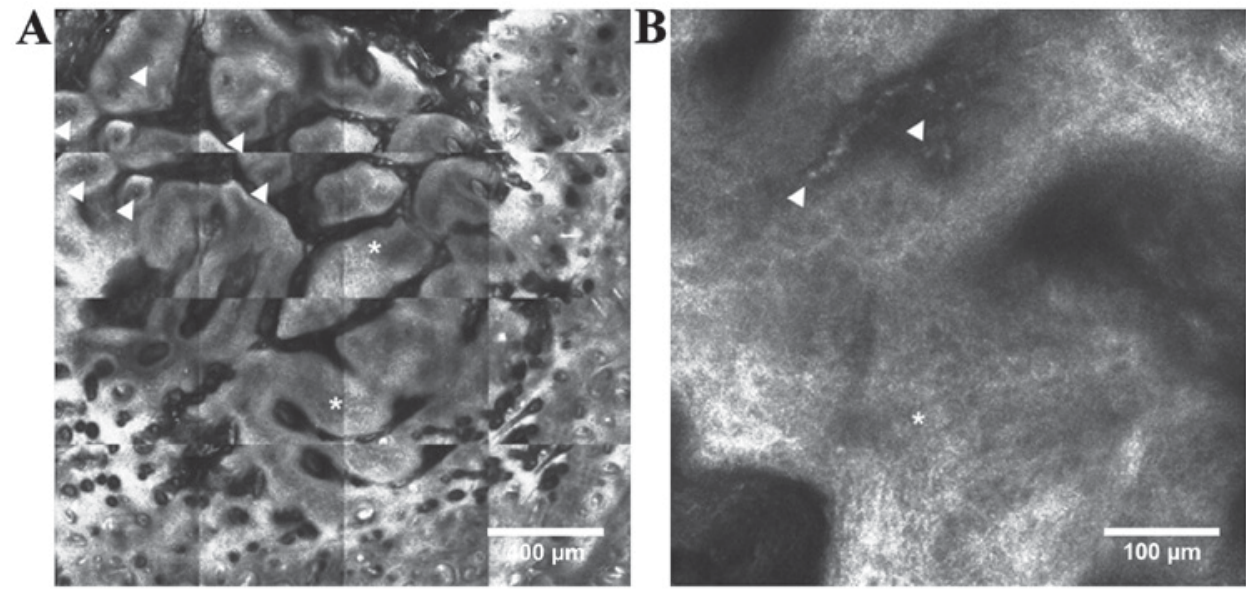

Figure 5. Chemically induced carcinogenesis in CD1-Foxn1nu mouse. (A) RCM mosaic (2x2 mm) showing a tumor with multi-lobular structure with altered keratinocyte architecture (white asterisks) and numerous blood vessels (white arrowheads); (B) detailed RCM image (500x500 $\mu \mathrm{m}$ ) showing atypical cells (white asterisk) and an enlarged, tortuous blood vessel (white arrowheads).

increasing incidence of skin cancer. In addition to the recognized genetic and environmental factors (93), prolonged exposure to pro-inflammatory cytokines and chemokines within chronic inflammation is experimentally sustained to favor initiation and progression of skin cancer (94).

Mouse models of chemically induced skin carcinogenesis are one of the most available and cost-effective models to analyze early alterations and pathways involved in skin tumorigenesis (95). The two-stage skin carcinogenesis model has been used to study mechanisms of epithelial cancers (96) and it refers to the two-step topical administration of chemicals to mouse skin for the initiation and promotion phases of skin tumorigenesis. This delimitation of phases allows the observation of premalignant lesions (96) and it offers more reliable results when testing the effects of environmental factors and drugs on skin tumors (95).

In vivo CLSM is a new imaging technology, not yet fully explored for investigating murine skin structures within experimental tumorigenesis. Reflectance mode CLSM was reported to allow real-time observation of abnormal tissue architecture, atypical structures, as well as the blood flow and vasculature that accompanies skin tumors (95) (Fig. 5). Dendritic immune cells are difficult to differentiate from melanocytes under RCM as they have similar morphologic features (97), but activated Langerhans cells seem to have a more superficial epidermal localization (41).

Fluorescence mode CLSM studies have been done on transgenic mice using green fluorescent protein marker to visualize cellular details of the skin (11). As it allows sequential noninvasive examination of the same skin area, CLSM technology seems to be ideal for monitoring tumor progression (98) and therapeutic effects of anticancer agents in mouse models of skin carcinogenesis (95). Recently, a dual mode in vivo reflectance and fluorescence CLSM has been developed and holds significant promise for imaging tumor progression in murine skin (98). This system combines the fluorescence contrast of targeted tumor cells with the acquired reflectance contrast of examined cells and tissues and place them within a histologically meaningful framework (98). In addition to the in situ visualization of tumor cell proliferation and vascular structures, it has been shown that combined reflectance/fluorescence in vivo CLSM has the ability to image dendritic immune cell trafficking to inoculated tumors and to monitor tumor induced immune response in the skin (98). 


\section{Limitations and future perspectives}

Despite the great advantages CLSM adds to dermatological practice, it also has some limitations, the most recognized being the restricted depth of penetration to 200-300 $\mu \mathrm{m}$, that allows imaging only of the epidermis and upper dermis $(3,4)$. Therefore, the deeper part of the dermis and the hypodermis cannot be visualized using the currently commercially available confocal microscopes. Examination of deeper skin structures could be achieved using higher laser power, but at the expense of damaging the skin area under evaluation (52). There are attempts to develop new devices that improve light collection from the examined plane in order to increase depth of penetration (99). Moreover, examination of skin lesions by means of CLSM is more time consuming than clinical evaluation or dermoscopy and it needs training and experience for the interpretation of CLSM images. Recent technological breakthroughs have led to the development of new, smaller and more practical hand-held devices that offer faster image acquisition and allow the examination of lesions located in less accessible body areas (52). Unlike vertical sections obtained in conventional histology, CLSM enables virtual sectioning of the skin at different depths, in horizontal planes (en face), parallel to the skin surface (3). For a better correlation with histology sections, current efforts are aimed at developing devices that could also perform optical sections of vertical planes and then compile 3-D reconstructions of the lesions (100). In addition, CLSM does not require tissue processing or coloring and images are obtained in greyscale, similar to X-rays or ultrasonography $(2,3)$. To improve contrast of epidermal and dermal structures and toward color-enhanced in vivo CSLM imaging, fluorescent dyes like indocyanine-green are being tested (101).

\section{Conclusions}

CLSM is a modern imaging technique that enables the noninvasive characterization of skin lesions located in the epidermis and superficial dermis with a high resolution. Currently, it is considered to be the most promising imaging technique for the quasi-microscopic morphological and dynamic characterization of superficial skin tumors. The in vivo mode adds the advantage of noninvasive, dynamic, in real-time assessment of the tumor associated vasculature and inflammation. It allows sequential noninvasive examination of the same skin area without causing any damage and to monitor disease progression and treatment outcome. Furthermore, CLSM technology seems to be ideal for monitoring tumor progression and therapeutic effects of anticancer agents in mouse models of experimental skin carcinogenesis.

\section{Acknowledgements}

Not applicable.

\section{Funding}

This study was partially supported by a grant of the Romanian Ministry of Research and Innovation (CCCDI-UEFISCDI; project no. 61PCCDI/2018 PN-III-P1-1.2-PCCDI-2017-0341) within PNCDI-III.

\section{Availability of data and materials}

The datasets used and/or analyzed during the current study are available from the corresponding author on reasonable request.

\section{Authors' contributions}

MAI, CC, ML, DL, MT, SGR, AB, CC, MN, SAZ and DB were responsible for acquisition of references, analysis and systematization of data, and contributed to writing the manuscript and revising it critically for important intellectual content. All authors read and approved the final version of the manuscript.

\section{Ethics approval and consent to participate}

Not applicable.

\section{Patient consent for publication}

Not applicable.

\section{Competing interests}

The authors declare that they have no competing interests.

\section{References}

1. Diaconeasa A, Boda D, Neagu M, Constantin C, Căruntu C, Vlădău L and Guţu D: The role of confocal microscopy in the dermato-oncology practice. J Med Life 4: 63-74, 2011.

2. Aghassi D, González E, Anderson RR, Rajadhyaksha M and González S: Elucidating the pulsed-dye laser treatment of sebaceous hyperplasia in vivo with real-time confocal scanning laser microscopy. J Am Acad Dermatol 43: 49-53, 2000.

3. González S, Swindells K, Rajadhyaksha M and Torres A: Changing paradigms in dermatology: Confocal microscopy in clinical and surgical dermatology. Clin Dermatol 21: 359-369, 2003.

4. Rajadhyaksha M, González S, Zavislan JM, Anderson RR and Webb RH: In vivo confocal scanning laser microscopy of human skin II: Advances in instrumentation and comparison with histology. J Invest Dermatol 113: 293-303, 1999.

5. González S, Sackstein R, Anderson RR and Rajadhyaksha M: Real-time evidence of in vivo leukocyte trafficking in human skin by reflectance confocal microscopy. J Invest Dermatol 117: 384-386, 2001.

6. Peppelman M, Wolberink EA, Gerritsen MJ, van de Kerkhof PC and van Erp PE: Application of leukotriene B4 and reflectance confocal microscopy as a noninvasive in vivo model to study the dynamics of skin inflammation. Skin Res Technol 21: 232-240, 2015.

7. Batani A, Brănișteanu DE, Ilie MA, Boda D, Ianosi S, Ianosi G and Caruntu C: Assessment of dermal papillary and microvascular parameters in psoriasis vulgaris using in vivo reflectance confocal microscopy. Exp Ther Med 15: 1241-1246, 2018.

8. Căruntu C, Boda D, Căruntu A, Rotaru M, Baderca F and Zurac S: In vivo imaging techniques for psoriatic lesions. Rom J Morphol Embryol 55 (Suppl 3): 1191-1196, 2014.

9. Ghiţă MA, Căruntu C, Rosca AE, Căruntu A, Moraru L, Constantin C, Neagu M and Boda D: Real-time investigation of skin blood flow changes induced by topical capsaicin. Acta Dermatovenerol Croat 25: 223-227, 2017.

10. Căruntu C and Boda D: Evaluation through in vivo reflectance confocal microscopy of the cutaneous neurogenic inflammatory reaction induced by capsaicin in human subjects. J Biomed Opt 17: 085003, 2012. 
11. Okabe M, Ikawa M, Kominami K, Nakanishi T and Nishimune $Y$ : 'Green mice' as a source of ubiquitous green cells. FEBS Lett 407: 313-319, 1997.

12. Meyer LE, Otberg N, Sterry W and Lademann J: In vivo confocal scanning laser microscopy: Comparison of the reflectance and fluorescence mode by imaging human skin. J Biomed Opt 11: 044012, 2006.

13. Skvara H, Plut U, Schmid JA and Jonak C: Combining in vivo reflectance with fluorescence confocal microscopy provides additive information on skin morphology. Dermatol Pract Concept 2: 3-12, 2012.

14. Rajadhyaksha M, Grossman M, Esterowitz D, Webb RH and Anderson RR: In vivo confocal scanning laser microscopy of human skin: Melanin provides strong contrast. J Invest Dermatol 104: 946-952, 1995.

15. Pellacani G, Guitera P, Longo C, Avramidis M, Seidenari S and Menzies S: The impact of in vivo reflectance confocal microscopy for the diagnostic accuracy of melanoma and equivocal melanocytic lesions. J Invest Dermatol 127: 2759-2765, 2007.

16. Guida S, Longo C, Casari A, Ciardo S, Manfredini M, Reggiani C, Pellacani G and Farnetani F: Update on the use of confocal microscopy in melanoma and non-melanoma skin cancer. G Ital Dermatol Venereol 150: 547-563, 2015.

17. Pellacani G, De Pace B, Reggiani C, Cesinaro AM, Argenziano G, Zalaudek I, Soyer HP and Longo C: Distinct melanoma types based on reflectance confocal microscopy. Exp Dermatol 23: 414-418, 2014

18. Serban ED, Farnetani F, Pellacani G and Constantin MM: Role of in vivo reflectance confocal microscopy in the analysis of melanocytic lesions. Acta Dermatovenerol Croat 26: 64-67, 2018.

19. González S, Sánchez V, González-Rodríguez A, Parrado C and Ullrich M: Confocal microscopy patterns in nonmelanoma skin cancer and clinical applications. Actas Dermosifiliogr 105: 446-458, 2014

20. Białek-Galas K, Wielowieyska-Szybińska D, Dyduch G and Wojas-Pelc A: The use of reflectance confocal microscopy in selected inflammatory skin diseases. Pol J Pathol 66: 103-108, 2015.

21. Constantin MM, Bucur S, Serban DE, Caruntu C, Orzan OA and Constantin T: Dermoscopic and laser confocal features of an exogenous ochronosis case. G Ital Dermatol Venereol: Jun 29, 2018 (Epub ahead of print).

22. Lange-Asschenfeldt S, Bob A, Terhorst D, Ulrich M, Fluhr J, Mendez G, Roewert-Huber HJ, Stockfleth E and Lange-Asschenfeldt B: Applicability of confocal laser scanning microscopy for evaluation and monitoring of cutaneous wound healing. J Biomed Opt 17: 076016, 2012.

23. Altintas AA, Altintas MA, Ipaktchi K, Guggenheim M, Theodorou P, Amini P and Spilker G: Assessment of microcirculatory influence on cellular morphology in human burn wound healing using reflectance-mode-confocal microscopy. Wound Repair Regen 17: 498-504, 2009.

24. Altintas AA, Guggenheim M, Oezcelik A, Gehl B, Aust MC and Altintas MA: Local burn versus local cold induced acute effects on in vivo microcirculation and histomorphology of the human skin. Microsc Res Tech 74: 963-969, 2011.

25. Longo C, Ragazzi M, Rajadhyaksha M, Nehal K, Bennassar A Pellacani $\mathrm{G}$ and Malvehy Guilera J: In vivo and ex vivo confocal microscopy for dermatologic and Mohs surgeons. Dermatol Clin 34: 497-504, 2016.

26. Bennàssar A, Vilata $\mathrm{A}$, Puig $\mathrm{S}$ and Malvehy J: Ex vivo fluorescence confocal microscopy for fast evaluation of tumour margins during Mohs surgery. Br J Dermatol 170: 360-365, 2014.

27. Miller DL and Weinstock MA: Nonmelanoma skin cancer in the United States: Incidence. J Am Acad Dermatol 30: 774-778, 1994.

28. Lomas A, Leonardi-Bee J and Bath-Hextall F: A systematic review of worldwide incidence of nonmelanoma skin cancer. $\mathrm{Br}$ J Dermatol 166: 1069-1080, 2012.

29. Chen CS, Sierra H, Cordova M and Rajadhyaksha M: Confocal microscopy-guided laser ablation for superficial and early nodular Basal cell carcinoma: A promising surgical alternative for superficial skin cancers. JAMA Dermatol 150: 994-998, 2014.

30. Lupu M, Caruntu C, Ghita MA, Voiculescu V, Voiculescu S, Rosca AE, Caruntu A, Moraru L, Popa IM, Calenic B, et al: Gene expression and proteome analysis as sources of biomarkers in basal cell carcinoma. Dis Markers 2016: 9831237, 2016.
31. Ghita MA, Caruntu C, Rosca AE, Kaleshi H, Caruntu A, Moraru L, Docea AO, Zurac S, Boda D, Neagu M, et al: Reflectance confocal microscopy and dermoscopy for in vivo, non-invasive skin imaging of superficial basal cell carcinoma. Oncol Lett 11: 3019-3024, 2016.

32. Longo C, Lallas A, Kyrgidis A, Rabinovitz H, Moscarella E, Ciardo S, Zalaudek I, Oliviero M, Losi A, Gonzalez S, et al: Classifying distinct basal cell carcinoma subtype by means of dermatoscopy and reflectance confocal microscopy. J Am Acad Dermatol 71: 716-724, 2014.

33. Căruntu C, Boda D, Guţu DE and Căruntu A: In vivo reflectance confocal microscopy of basal cell carcinoma with cystic degeneration. Rom J Morphol Embryol 55: 1437-1441, 2014.

34. Peppelman M, Wolberink EA, Blokx WA, van de Kerkhof PC, van Erp PE and Gerritsen MJ: In vivo diagnosis of basal cell carcinoma subtype by reflectance confocal microscopy. Dermatology 227: 255-262, 2013.

35. Nori S, Rius-Díaz F, Cuevas J, Goldgeier M, Jaen P, Torres A and González S: Sensitivity and specificity of reflectancemode confocal microscopy for in vivo diagnosis of basal cell carcinoma: A multicenter study. J Am Acad Dermatol 51: 923-930, 2004

36. González S and Tannous Z: Real-time, in vivo confocal reflectance microscopy of basal cell carcinoma. J Am Acad Dermatol 47: 869-874, 2002

37. Stephens A, Fraga-Braghiroli N, Oliviero M, Rabinovitz H and Scope A: Spoke wheel-like structures in superficial basal cell carcinoma: A correlation between dermoscopy, histopathology, and reflective confocal microscopy. J Am Acad Dermatol 69: e219-e221, 2013

38. Ulrich M, Roewert-Huber J, González S, Rius-Diaz F, Stockfleth E and Kanitakis J: Peritumoral clefting in basal cell carcinoma: Correlation of in vivo reflectance confocal microscopy and routine histology. J Cutan Pathol 38: 190-195, 2011.

39. Que SK, Fraga-Braghiroli N, Grant-Kels JM, Rabinovitz HS, Oliviero $\mathrm{M}$ and Scope A: Through the looking glass: Basics and principles of reflectance confocal microscopy. J Am Acad Dermatol 73: 276-284, 2015.

40. Lupu M, Caruntu C, Solomon I, Popa A, Lisievici C, Draghici C, Papagheorghe L, Voiculescu VM and Giurcaneanu C: The use of in vivo reflectance confocal microscopy and dermoscopy in the preoperative determination of basal cell carcinoma histopathological subtypes. DermatoVenerol 62: 7-13, 2017.

41. Segura S, Puig S, Carrera C, Palou J and Malvehy J: Dendritic cells in pigmented basal cell carcinoma: A relevant finding by reflectance-mode confocal microscopy. Arch Dermatol 143: 883-886, 2007.

42. Pan ZY, Lin JR, Cheng TT, Wu JQ and Wu WY: In vivo reflectance confocal microscopy of basal cell carcinoma: Feasibility of preoperative mapping of cancer margins. Dermatol Surg 38: 1945-1950, 2012.

43. Webber SA, Wurm EMT, Douglas NC, Lambie D, Longo C, Pellacani G and Soyer HP: Effectiveness and limitations of reflectance confocal microscopy in detecting persistence of basal cell carcinomas: A preliminary study. Australas J Dermatol 52: 179-185, 2011.

44. Ahlgrimm-Siess V, Horn M, Koller S, Ludwig R, Gerger A and Hofmann-Wellenhof R: Monitoring efficacy of cryotherapy for superficial basal cell carcinomas with in vivo reflectance confocal microscopy: A preliminary study. J Dermatol Sci 53: 60-64, 2009

45. Voiculescu V, Calenic B, Ghita M, Lupu M, Caruntu A, Moraru L, Voiculescu S, Ion A, Greabu M, Ishkitiev N, et al: From normal skin to squamous cell carcinoma: A quest for novel biomarkers. Dis Markers 2016: 4517492, 2016.

46. Boda D, Neagu M, Constantin C, Voinescu RN, Caruntu C, Zurac S, Spandidos DA, Drakoulis N, Tsoukalas D and Tsatsakis AM: HPV strain distribution in patients with genital warts in a female population sample. Oncol Lett 12: 1779-1782, 2016.

47. Boda D, Docea AO, Calina D, Ilie MA, Caruntu C, Zurac S, Neagu M, Constantin C, Branisteanu DE, Voiculescu V, et al: Human papilloma virus: Apprehending the link with carcinogenesis and unveiling new research avenues (Review). Int J Oncol 52: 637-655, 2018.

48. Georgescu SR, Sârbu MI, Matei C, Ilie MA, Caruntu C, Constantin C, Neagu M and Tampa M: Capsaicin: Friend or foe in skin cancer and other related malignancies? Nutrients 9: 1365, 2017. 
49. Lupu M, Caruntu A, Caruntu C, Papagheorghe LML, Ilie MA, Voiculescu V, Boda D, Constantin C, Tanase C, Sifaki M, et al: Neuroendocrine factors: The missing link in non-melanoma skin cancer (Review). Oncol Rep 38: 1327-1340, 2017.

50. Solomon I, Voiculescu VM, Caruntu C, Lupu M, Popa A Ilie MA, Albulescu R, Caruntu A, Tanase C, Constantin C, et al: Neuroendocrine factors and head and neck squamous cell carcinoma: An affair to remember. Dis Markers 2018: 9787831 , 2018.

51. Tampa M, Caruntu C, Mitran M, Mitran C, Sarbu I, Rusu LC, Matei C, Constantin C, Neagu M and Georgescu SR: Markers of oral lichen planus malignant transformation. Dis Markers 2018 1959506, 2018.

52. González S and Ahlgrimm-Siess V: Reflectance confocal microscopy in dermatology: Fundamentals and clinical applications. Aula Médica, p111, 2012

53. Rossi R, Mori M and Lotti T: Actinic keratosis. Int J Dermatol 46 895-904, 2007.

54. Wolff K and Johnson RA: Fitzpatrick's Color Atlas and Synopsis of Clinical Dermatology. 6th edition. McGraw-Hill, New York, NY, pp267-270, 2009.

55. Aghassi D, Anderson RR and González S: Confocal laser microscopic imaging of actinic keratoses in vivo: A preliminary report. J Am Acad Dermatol 43: 42-48, 2000.

56. Peppelman M, Nguyen KP, Hoogedoorn L, van Erp PE and Gerritsen MJ: Reflectance confocal microscopy: Non-invasive distinction between actinic keratosis and squamous cell carcinoma. J Eur Acad Dermatol Venereol 29: 1302-1309, 2015.

57. Rishpon A, Kim N, Scope A, Porges L, Oliviero MC, Braun RP Marghoob AA, Fox CA and Rabinovitz HS: Reflectance confocal microscopy criteria for squamous cell carcinomas and actinic keratoses. Arch Dermatol 145: 766-772, 2009.

58. Branzan AL, Landthaler M and Szeimies RM: In vivo confocal scanning laser microscopy in dermatology. Lasers Med Sci 22: 73-82, 2007

59. Chung VQ, Dwyer PJ, Nehal KS, Rajadhyaksha M, Menaker GM, Charles C and Jiang SB: Use of ex vivo confocal scanning laser microscopy during Mohs surgery for nonmelanoma skin cancers. Dermatol Surg 30: 1470-1478, 2004.

60. Lupu M, Caruntu A, Caruntu C, Boda D, Moraru L, Voiculescu V and Bastian A: Non-invasive imaging of actinic cheilitis and squamous cell carcinoma of the lip. Mol Clin Oncol 8: 640-646, 2018

61. Clark AL, Gillenwater AM, Collier TG, Alizadeh-Naderi R, El-Naggar AK and Richards-Kortum RR: Confocal microscopy for real-time detection of oral cavity neoplasia. Clin Cancer Res 9: 4714-4721, 2003

62. Zurac S, Neagu M, Constantin C, Cioplea M, Nedelcu R, Bastian A, Popp C, Nichita L, Andrei R, Tebeica T, et al: Variations in the expression of TIMP1, TIMP2 and TIMP3 in cutaneous melanoma with regression and their possible function as prognostic predictors. Oncol Lett 11: 3354-3360, 2016.

63. Neagu M, Constantin C and Zurac S: Immune parameters in the prognosis and therapy monitoring of cutaneous melanoma patients: Experience, role, and limitations. BioMed Res Int 2013: 107940, 2013.

64. Neagu M, Constantin C, Manda G and Margaritescu I: Biomarkers of metastatic melanoma. Biomarkers Med 3: 71-89, 2009.

65. Neagu M, Constantin C and Tanase C: Immune-related biomarkers for diagnosis/prognosis and therapy monitoring of cutaneous melanoma. Expert Rev Mol Diagn 10: 897-919, 2010.

66. Surcel M, Constantin C, Caruntu C, Zurac S and Neagu M: Inflammatory cytokine pattern is sex-dependent in mouse cutaneous melanoma experimental model. J Immunol Res 2017 : 9212134, 2017.

67. Caruntu C, Mirica A, Rosca A, Mirica R, Caruntu A, Tampa M, Matei C, Constantin C, Neagu M, Badarau A, et al: The role of estrogens and estrogen receptors in melanoma development and progression. Acta Endo Buc 12: 234-241, 2016.

68. Caruntu C, Boda D, Constantin C, Caruntu A and Neagu M: Catecholamines increase in vitro proliferation of murine B16F10 melanoma cells. Acta Endo Buc 10: 545-558, 2014.

69. Neagu M, Constantin C, Dumitrascu GR, Lupu AR, Caruntu C, Boda D and Zurac S: Inflammation markers in cutaneous melanoma - edgy biomarkers for prognosis. Discoveries (Craiova) 3: e38, 2015

70. Ene CD, Anghel AE, Neagu M and Nicolae I: $25-\mathrm{OH}$ vitamin D and interleukin-8: Emerging biomarkers in cutaneous melanoma development and progression. Mediators Inflamm 2015: 904876 , 2015 .
71. Solovastru LG, Vâta D, Statescu L, Constantin MM and Andrese E: Skin cancer between myth and reality, yet ethically constrained. Rev Rom Bioet 12: 47-52, 2014.

72. Rigel DS, Friedman RJ, Kopf AW and Polsky D: ABCDE - an evolving concept in the early detection of melanoma. Arch Dermatol 141: 1032-1034, 2005.

73. Grob JJ and Bonerandi JJ: The 'ugly duckling' sign: Identification of the common characteristics of nevi in an individual as a basis for melanoma screening. Arch Dermatol 134: 103-104, 1998.

74. Hansen C, Wilkinson D, Hansen M and Argenziano G: How good are skin cancer clinics at melanoma detection? Number needed to treat variability across a national clinic group in Australia. J Am Acad Dermatol 61: 599-604, 2009.

75. Sidhu S, Bodger O, Williams N and Roberts DL: The number of benign moles excised for each malignant melanoma: The number needed to treat. Clin Exp Dermatol 37: 6-9, 2012.

76. Goodson AG, Florell SR, Hyde M, Bowen GM and Grossman D: Comparative analysis of total body and dermatoscopic photographic monitoring of nevi in similar patient populations at risk for cutaneous melanoma. Dermatol Surg 36: 1087-1098, 2010.

77. Moloney FJ, Guitera P, Coates E, Haass NK, Ho K, Khoury R, O'Connell RL, Raudonikis L, Schmid H, Mann GJ, et al: Detection of primary melanoma in individuals at extreme high risk: A prospective 5-year follow-up study. JAMA Dermatol 150: 819-827, 2014.

78. March J, Hand M and Grossman D: Practical application of new technologies for melanoma diagnosis: Part I. Noninvasive approaches. J Am Acad Dermatol 72: 929-942, 2015.

79. Ulrich M and Lange-Asschenfeldt S: In vivo confocal microscopy in dermatology: From research to clinical application. J Biomed Opt 18: 061212, 2013.

80. Carrera C, Puig S and Malvehy J: In vivo confocal reflectance microscopy in melanoma. Dermatol Ther (Heidelb) 25: 410-422, 2012.

81. Longo C, Farnetani F, Ciardo S, Cesinaro AM, Moscarella E, Ponti G, Zalaudek I, Argenziano G and Pellacani G: Is confocal microscopy a valuable tool in diagnosing nodular lesions? A study of 140 cases. Br J Dermatol 169: 58-67, 2013.

82. Gerger A, Koller S, Weger W, Richtig E, Kerl H, Samonigg H, Krippl P and Smolle J: Sensitivity and specificity of confocal laser-scanning microscopy for in vivo diagnosis of malignant skin tumors. Cancer 107: 193-200, 2006.

83. Sokołowska-Wojdyło M, Olek-Hrab K and RuckemannDziurdzińska K: Primary cutaneous lymphomas: Diagnosis and treatment. Postepy Dermatol Alergol 32: 368-383, 2015.

84. Ion A, Popa IM, Papagheorghe LML, Lisievici C, Lupu M, Voiculescu V, Caruntu C and Boda D: Proteomic approaches to biomarker discovery in cutaneous T-cell lymphoma. Dis Markers 2016: 9602472, 2016.

85. Fabbrocini G, Mazzella C, Cantelli M, Baldo A, Russo D, De Rosa G and Monfrecola G: Reflectance confocal microscopy as new diagnostic tool in folliculotropic mycosis fungoides. Skin Appendage Disord 4: 118-121, 2018.

86. Mancebo SE, Cordova M, Myskowski PL, Flores ES, Busam K, Jawed SI, Skripnik A, Rajadhyaksha M and Querfeld C: Reflectance confocal microscopy features of mycosis fungoides and Sézary syndrome: Correlation with histopathologic and T-cell receptor rearrangement studies. J Cutan Pathol 43 505-515, 2016.

87. Li W, Dai H, Li Z and Xu AE: Reflectance confocal microscopy for the characterization of mycosis fungoides and correlation with histology: A pilot study. Skin Res Technol 19: 352-355, 2013.

88. Lange-Asschenfeldt S, Babilli J, Beyer M, Ríus-Diaz F, González S, Stockfleth E and Ulrich M: Consistency and distribution of reflectance confocal microscopy features for diagnosis of cutaneous T cell lymphoma. J Biomed Opt 17: 016001, 2012.

89. Koller S, Gerger A, Ahlgrimm-Siess V, Weger W, Smolle J and Hofmann-Wellenhof R: In vivo reflectance confocal microscopy of erythematosquamous skin diseases. Exp Dermatol 18 536-540, 2009.

90. Agero AL, Gill M, Ardigo M, Myskowski P, Halpern AC and González S: In vivo reflectance confocal microscopy of mycosis fungoides: A preliminary study. J Am Acad Dermatol 57: 435-441, 2007

91. Ardigò M, Donadio C, Vega H, Cota C, Moscarella E and Agozzino M: Concordance between in vivo reflectance confocal microscopy and optical histology of lymphomatoid papulosis. Skin Res Technol 19: 308-313, 2013. 
92. Ardigò M,El Shabrawi-Caelen L and Tosti A: In vivo reflectance confocal microscopy assessment of the therapeutic follow-up of cutaneous T-cell lymphomas causing scalp alopecia. Dermatol Ther (Heidelb) 27: 248-251, 2014.

93.de Vries E, Trakatelli M, Kalabalikis D, Ferrandiz L, Ruiz-de-Casas A, Moreno-Ramirez D, Sotiriadis D, Ioannides D, Aquilina S, Apap C, et al; EPIDERM Group: Known and potential new risk factors for skin cancer in European populations: A multicentre case-control study. Br J Dermatol 167 (Suppl 2): 1-13, 2012.

94. Maru GB, Gandhi K, Ramchandani A and Kumar G: The role of inflammation in skin cancer: Adv Exp Med Biol 816: 437-469, 2014.

95. Neagu M, Caruntu C, Constantin C, Boda D, Zurac S, Spandidos DA and Tsatsakis AM: Chemically induced skin carcinogenesis: Updates in experimental models (Review). Oncol Rep 35: 2516-2528, 2016.

96. Abel EL, Angel JM, Kiguchi K and DiGiovanni J: Multi-stage chemical carcinogenesis in mouse skin: Fundamentals and applications. Nat Protoc 4: 1350-1362, 2009.

97.Hashemi P, Pulitzer MP, Scope A, Kovalyshyn I, Halpern AC and Marghoob AA: Langerhans cells and melanocytes share similar morphologic features under in vivo reflectance confocal microscopy: A challenge for melanoma diagnosis. J Am Acad Dermatol 66: 452-462, 2012.
98. Li Y, Gonzalez S, Terwey TH, Wolchok J, Li Y, Aranda I, Toledo-Crow R and Halpern AC: Dual mode reflectance and fluorescence confocal laser scanning microscopy for in vivo imaging melanoma progression in murine skin. J Invest Dermatol 125: 798-804, 2005.

99.Izatt JA, Kulkarni MD, Hsing-Wen W, Kobayashi K and Sivak MV: Optical coherence tomography and microscopy in gastrointestinal tissues. IEEE J Sel Top Quantum Electron 2: 1017-1028, 1996.

100. Ono I, Sakemoto A, Ogino J, Kamiya T, Yamashita T and Jimbow K: The real-time, three-dimensional analyses of benign and malignant skin tumors by confocal laser scanning microscopy. J Dermatol Sci 43: 135-141, 2006.

101. Skvara H, Kittler H, Schmid JA, Plut U and Jonak C: In vivo fluorescence confocal microscopy: Indocyanine green enhances the contrast of epidermal and dermal structures. J Biomed Opt 16: 096010, 2011.

This work is licensed under a Creative Commons Attribution-NonCommercial-NoDerivatives 4.0 International (CC BY-NC-ND 4.0) License. 